\title{
Identification of Susceptible Weed Hosts of Phytophthora spp. in Cocoa Trees in the Nawa Region, South-West of Côte d'Ivoire
}

\author{
Yapi Richmond Baka ${ }^{1^{*}}$, Daniel Kouamé Kra², David Coulibaly N'golo ${ }^{3}$ \\ and Ipou Joseph Ipou ${ }^{1}$ \\ ${ }^{1}$ Laboratory of Botany, Université Félix Houphouët-Boigny, UFR Biosciences, 22 BP 582 Abidjan 22, \\ Côte d'Ivoire. \\ ${ }^{2}$ Plant Heath Unit, Université Nangui Abrogoua, UFR Sciences de la Nature, 02 BP 801 Abidjan 02, \\ Côte d'lvoire. \\ ${ }^{3}$ Pasteur Institute of Côte d'Ivoire, Adiopodoumé Molecular Biology Platform, 01 BP 490 Abidjan 01, \\ Côte d'Ivoire. \\ Authors' contributions \\ This work was carried out in collaboration between all authors. Author YRB wrote the protocol, \\ collected, analyzed the data and wrote the manuscrit. Author IJP designed and supervised the work. \\ Authors DKK and DCN supervised also the work and further analyzed data. All authors read and \\ approved the final manuscript. \\ Article Information \\ DOI: $10.9734 / A R R B / 2021 / v 36 i 130333$ \\ Editor(s): \\ (1) Dr. Rishee K. Kalaria, Navsari Agricultural University, India. \\ Reviewers: \\ (1) S. Elain Apshara, ICAR- CPCRI, India. \\ (2) Bilal Saeed Khan, University of Agriculture, Pakistan. \\ Complete Peer review History: http://www.sdiarticle4.com/review-history/65515
}

Original Research Article

Received 10 December 2020

Accepted 13 February 2021

Published 12 March 2021

\begin{abstract}
The cocoa tree, the mainexport crop in Côte d'Ivoire is frequently attacked by a disease: brown pod rot, caused by Phytophthora spp. which causes a considerable drop in production. This soil-borne pathogen attacks on so-called weeds when environmental conditions are favourable. The presence of these susceptible weed hosts can amplify this scourge of brown rot by transmitting the pathogen to the crop plant. In order to improve the yield of this crop, a study was conducted in the Nawa region to identify the weed hosts through the characterization of the pathogen.

This study consisted first in the inventory of susceptible host weeds of Phytophthora spp. and second in the morphological characterization of the pathogen.
\end{abstract}


Concerning the host weeds inventory we procceeded determining all symptomatic weeds located within $3 \mathrm{~m}$ of the cocoa plants affected by brown rot.

We identified 48 susceptible host species, divided into 41 genera and 22 families and we observed brown spots on the leaves of Oplismenus burmannii and Laportea aestuans; on the leaves of Clerodendrum splendens and Xanthosoma mafaffa, brown necroses surrounded by a yellow halo were noticed. Oily brown spots were examined on the leaves of Ageratum conyzoides. On the proximal, lateral and distal parts of the pods symptoms of brown spots covered with whitish mycelia were observed. Phytophthora strains obtained from the pods and weeds on PDA culture medium were characterized by matted, white mycelial colonies with a cottony appearance. Microscopic features revealed the presence of sporocysts, oospores and chlamydospores of different shapes.

Keywords: Cocoa tree; weeds; phytophthora; symptoms; morphological characterization.

\section{INTRODUCTION}

Côte d'Ivoire is an agricultural country which based its economy on coffee and cocoa culture. During the 2015-2016 farming operation, the Ivory Coast, the leading cocoa producer, provided $35 \%$ of world production with an annual production of 1.7 million tones [1]. Crops such as cotton and cashew nuts occupied $7 \%$ of the land each. Oil palm and rubber trees covered $5 \%$ and $3 \%$ of the land respectively. Other cash crops (coconut, dessert banana, etc.) accounted for $3 \%$ of the land area overall [1]. Thus, coffee and cocoa play a key role in the Ivorian economy. The cocoa economy involves nearly 700,000 farmers and provides a livelihood for 4 million people, or $25 \%$ of the Ivorian population [2].

The world production of cocoa which is 3.6 millio $\mathrm{n}$ tons [3], position Côte d'Ivoire at the forefront of the world supply. This performance is partly due to the sanitary state and especially to the maintenance provided by producers on cocoa plantations. Today, beyond the attacks of harmful insects such as Mirides [4], the cocoa crop that forms the basis of the Ivorian economy is facing other constraints. Indeed, it is subject to numerous parasitic attacks, in particular Phytophthora palmivora and Phytophthora megakarya, which cause "brown pod rot" [5]. This disease directly results in yield losses as affected pods produce cocoa beans that are unfit for consumption. The disease is spread by spores of this pathogen dispersed by rain, wind, insects, and some mammals such as rats and bats [6]. Apart from these sources of spread, some weeds or weeds found in cocoa farms could be considered as reservoirs. These may show symptoms similar to those observed on diseased cocoa trees. Indeed, weeds have attributes that make them difficult to control [7] both in cocoa and other crops. They also serve as hosts for many pests, including insects, viruses and fungi. Weeds are therefore a real problem for agriculture in general and for cocoa farming in particular.

The objective of this study was to contribute to the improvement of cocoa crops by identifying susceptible host weeds of Phytophthora spp. in order to alert cocoa industry stakeholders to the impact of these weeds on cocoa crop production.

\section{MATERIALS AND METHODS}

\section{1 Study Area}

This study was conducted in the southwestern part of Côte d'Ivoire in the Nawa region. It is located between $6^{\circ} 12^{\prime}$ and $7^{\circ} 08^{\prime}$ West longitudes and $5^{\circ} 19^{\prime}$ and $6^{\circ} 34^{\prime}$ North latitudes. This region, born from the split of the former Lower Sassandra Region, has Soubré as its chief town. It is bordered to the North by the Regions of Guémon and Haut -Sassandra; to the South by the Regions of Gbôklè and San-Pedro; to the East by the Regions of Goh and Loh Djibouo and to the West by the Region of Cavally. The region includes the Departments of Soubré, Buyo, Méagui and Guéyo

\subsection{Study Material}

The biological material consisted of cocoa trees plant and weeds likely to be hosts of Phytophthora spp. and fungal material, i.e. Phytophthora strains isolated from pods and symptomatic weeds.

\subsection{Methods}

\subsubsection{Sampling of pods and host weeds}

One or two symptomatic pods are removed from each cocoa tree affected by brown rot. Weed 
sampling was carried out $3 \mathrm{~m}$ from the diseased cocoa trees, covering an area of $28.26 \mathrm{~m}^{2}$. From the symptomatic plants in this area, tissue samples were taken from the diseased organs.

\subsubsection{Isolation from surface flaming pods and weeds}

Pods showing symptoms of brown rot were rinsed with tap water. The cortex was cleaned with alcohol at $70^{\circ} \mathrm{C}$ with paper towels and then placed under a laminar flow hood (CRUMA model CR870FL series VTR571316). They were then soaked in alcohol and flambeed. Using a sterile punch, tissue fragments were removed from the subcortical tissues at the growth fronts of the brown rot. Washers were placed on poor medium (agar water culture medium) in 90 $\mathrm{mm}$ diameter petri dishes.

For weeds, the necrotic leaf and stem organs were washed with tap water and placed in jars after removing fragments of these organs at the growth front of the necrosis. Disinfection was carried out by putting $70 \%$ alcohol in the jars containing the fragments of these necrotic organs for 3 minutes. They were then soaked in a $5 \%$ sodium hypochlorite solution $(\mathrm{NaOCl})$ for 1 minute. After disinfection, these fragments were rinsed three times successively with sterilized distilled water and dried for 60 seconds before being transferred to the petri dishes containing the poor medium (agar water culture medium). After mycelium formation, the isolates obtained were successively transferred to the PDA culture medium.

\subsubsection{Identification of the pathogen}

Macroscopic observations focused on cultural traits such as thallus texture and color, and growth contour. Phytophthora strains were observed under optical microscope at X400 magnification. Microscopic observation was performed by removing with a sterile needle a mycelial fragment which was put between slide and lamina for observation

\subsubsection{Data analysis}

The data collected made it possible to establish the list of host weeds susceptible to Phytophthora and to carry out the analysis of the diversity of the flora.
The diversity of the flora makes it possible to determine the richness of the flora of a given environment. According to Ake-Assi [8], a flora is all the more diversified as it includes less large families and large multispecies genera. It is determined using the index of floristic diversity (Ids) and is expressed as follows:

$$
\text { Ids }=\frac{\mathbf{E}}{\mathbf{G}}
$$

Ids $=$ the floristic diversity index

$E=$ Number of species

$G=$ Number of gender

\section{RESULTS}

\subsection{Flora of Weed Hosts Susceptible to Phytophthora}

The weed inventory identified 48 susceptible host species of Phytophthora associated with cocoa (Table 1). These species are divided into 41 genera and belong to 22 families (Table 2). Among these families, the most notable (in bold) are Asteraceae, Fabaceae, Poaceae (Gramineae), Solanaceae and Verbenaceae. The taxa inventoried belong mainly to the class of Broadleaf $(85.06 \%)$ than to the class of Monocotyledons (14.94\%).

\subsection{Specific Diversity Index (Ids)}

The index of specific diversity allowed to note that Asteraceae (Ids $=1.12$ ) and Fabaceae (Ids $=1.2$ ) are the most diversified families. The Table 3 shows that these two families have the lowest specific diversity index. The Solanaceae and Verbernaceae, each with the highest species diversity indices (Ids $=3$ ), are the least diverse.

\subsection{Characteristics of Symptoms Caused by Phytophthora in the Field}

Various symptoms caused by Phytophthora were observed on pods and weeds. On the proximal, lateral and distal parts of the pods symptoms of brown spots were observed (Fig. 1). The brownish parts of the pods were covered with whitish mycelia. In addition, the brown spots on the surface of the pods were hard to the touch. 
Table 1. List of Phytophtohra susceptible weed hosts inventoried in cocoa farms

\begin{tabular}{|c|c|c|}
\hline No & Species & Families \\
\hline 1 & Acroceras zizanioides (Kunth) Dandy & Poaceae \\
\hline 2 & Ageratum conyzoides Linn. & Asteraceae \\
\hline 3 & Albizia zygia (DC.) J.F. Macbr. & Mimosaceae \\
\hline 4 & Alchornea cordifolia (Schum. \& Thonn.) Müll.Arg. & Euphorbiaceae \\
\hline 5 & Aneilema beniniense (P. Beauv.) Kunth & Commelinaceae \\
\hline 6 & Axonopus compressus (Sw.) P. Beauv. & Poaceae \\
\hline 7 & Baphia bancoensis Aubrév. & Fabaceae \\
\hline 8 & Bidens pilosa Linn. & Asteraceae \\
\hline 9 & Ceiba pentandra (Linn.) Gaerth. & Bombacaceae \\
\hline 10 & Celtis milbraedii Engl. & Ulmaceae \\
\hline 11 & Centrosema pubescens Benth. & Fabaceae \\
\hline 12 & Chromolaena odorata (L.) R. M. King \& H. Rob. & Asteraceae \\
\hline 13 & Clerodendrum splendens G. Don & Verbenaceae \\
\hline 14 & Clerodendrum umbellatum Poir. & Verbenaceae \\
\hline 15 & Clerodendrum volubile P. Beauv. & Verbenaceae \\
\hline 16 & Coccinia barteri (Hook.f.)Keay & Cucurbitaceae \\
\hline 17 & Crassocephalum biafrae (Oliv. \& Hiern) S.Moore & Asteraceae \\
\hline 18 & Croton hirtus L'Hérit. & Euphorbiaceae \\
\hline 19 & Cyathula prostrata (Linn.) BI. Var prostrata & Amaranthaceae \\
\hline 20 & Desmodium adscendens (Sw.) DC. var. adscendens & Fabaceae \\
\hline 21 & Desmodium scorpiurus (Sw.) Desv. & Fabaceae \\
\hline 22 & Emilia coccinea (Sims) G. Don & Asteraceae \\
\hline 23 & Emilia sonchifolia (Linn.) DC. & Asteraceae \\
\hline 24 & Ficus exasperata Vahl & Moraceae \\
\hline 25 & Ipomoea involucrata P. Beauv. & Convolvulaceae \\
\hline 26 & Justicia flava (Forssk.) Vahl & Acanthaceae \\
\hline 27 & Laportea aestuans (Linn.) Chew & Urticaceae \\
\hline 28 & Merremia Sp & Convolvulaceae \\
\hline 29 & Mikania cordata (Burm.f.) B.L. Robinson var. cordata & Asteraceae \\
\hline 30 & Morinda lucida Benth. & Rubiaceae \\
\hline 31 & Mucuna flagellipes Hook.f. & Fabaceae \\
\hline 32 & Oplismenus burmannii (Retz.) P. Beauv. & Poaceae \\
\hline 33 & $\begin{array}{l}\text { Oplismenus hirtellus (Linn.) P. Beauv. Subsp. Fasciculatus U. } \\
\text { Scholz }\end{array}$ & Poaceae \\
\hline 34 & Phaulopsis barteri (T. Anders.) Lindau & Acanthaceae \\
\hline 35 & Porrophylum ruderal & Asteraceae \\
\hline 36 & Pouzolzia guineensis Benth. & Urticaceae \\
\hline 37 & Pueraria phaseoloides (Roxb.) Benth. var javanica (Benth) Baker & Fabaceae \\
\hline 38 & Ruthalicia eglandulosa (Hook.f.) Jeffrey & Cucurbitaceae \\
\hline 39 & Solanum distichum Thonn. var. distichum & Solanaceae \\
\hline 40 & Solanum erianthum $D$. Don & Solanaceae \\
\hline 41 & Solanum rugosum Dun. & Solanaceae \\
\hline 42 & $\begin{array}{l}\text { Solenostemon monostachyus (P. Beauv.) Briq. subsp. } \\
\text { monostachyus }\end{array}$ & Lamiaceae \\
\hline 43 & Spathodea campanulata P. Beauv. & Bignoniaceae \\
\hline 44 & Spermacoce latifolia Aubl. & Rubiaceae \\
\hline 45 & Spigelia anthelmia Linn & Loganiaceae \\
\hline 46 & Synedrella nodiflora Gaertn & Asteraceae \\
\hline 47 & Telosma africanum (N.E. Br.) Colville & Asclepiadaceae \\
\hline 48 & Xanthosoma mafaffa Schott & Araceae \\
\hline
\end{tabular}

Necrosis was observed on the leaves and stems of the weeds sampled (Fig. 2). Brown spots were observed on the leaves of Oplismenus burmannii and Laportea aestuans. Oily brown spots were also observed on the leaves of Ageratum conyzoides. On the leaves of Clerodendrum 
splendens and Xanthosoma mafaffa, brown necroses surrounded by a yellow halo was noticed.

\subsection{Macroscopic Characteristics Isolated Phytophthora Strains}

Phytophthora strains obtained from the pods were characterized by white thallus with a cottony appearance. These strains present lined mycelial colonies that diffuse into the PDA culture medium (Fig. 3). These mycelial colonies without pigments have regular and irregular contours.

Concerning weeds, the strains of Phytophthora obtained are characterized by airy white thallus without pigments, regular and fluffy in appearance. Some strains, however, showed white mycelial colonies (Fig. 4).

\subsection{Microscopic Characteristics Isolated Phythophthora Strains}

At the microscopic level, all Phytophthora strains showed an unsegmented mycelium. These strains were distinguished by the presence of sporangia, clamydospores and different forms of Oospore (Fig 5 and Fig 6).

\section{DISCUSSION}

Analysis of the floristic richness of susceptible weed hosts of Phytophthora spp. revealed 48 species in 41 genera belonging to 22 families. The number of species obtained is the result of the specificity of our study. Indeed, our inventories were carried out only in cocoa plantations and targeted a specific category of plants, namely, hosts susceptible to Phytophthora. This specificity reduces the type and number of species to be counted, even if the plantations offer a higher range of weed species. This has been confirmed by the National Agricultural Research Centre of Côte d'Ivoire [9]. Their study consisted in identifying the host species of swollen shoot virus in cocoa production. During this study, 47 species divided into 26 genera and 15 families were inventoried. In addition to the work of CNRA, studies conducted by Singo [10] on the inventory of wild hosts of Achaea catocaloides in cocoa trees in Toumodi and Taabo Departments also confirmed this finding. This author has identified during his work, 61 species divided into 55 genera belonging to 34 families. These different results are thus quite close to ours. Contrary to the above-mentioned results, the results obtained during the work of

Table 2. Families of weed hosts susceptible to Phytophthora spp. in cocoa trees

\begin{tabular}{lll}
\hline Families & Number of genera & Number of species \\
\hline Acanthaceae & 2 & 2 \\
Amaranthaceae & 1 & 1 \\
Araceae & 1 & 1 \\
Asclepiadaceae & 1 & 1 \\
Asteraceae & 8 & 9 \\
Bignoniaceae & 1 & 1 \\
Bombacaceae & 1 & 1 \\
Commelinaceae & 1 & 1 \\
Convolvulaceae & 2 & 2 \\
Cucurbitaceae & 2 & 2 \\
Euphorbiaceae & 2 & 2 \\
Fabaceae & 5 & 6 \\
Lamiaceae & 1 & 1 \\
Loganiaceae & 1 & 1 \\
Mimosaceae & 1 & 1 \\
Moraceae & 1 & 1 \\
Poaceae & 3 & 4 \\
Rubiaceae & 2 & 2 \\
Solanaceae & 1 & 3 \\
Ulmaceae & 1 & 1 \\
Urticaceae & 2 & 2 \\
Verbenaceae & 1 & 3 \\
\hline
\end{tabular}


Kpangui [11] in cocoa trees in the sub-prefecture of Kokumbo in central Côte d'Ivoire differ from ours. He inventoried 384 species divided into 231 genera and 91 families. The same applies to the results obtained by Adou [12], whose studies were conducted in the cocoa and coffee plantations around the village of Moussadougou in the classified forest of Monogaga. During his work, he identified 309 species belonging to 106 families. Indeed, the work of these different authors covered all the flora of cocoa and coffee trees.

In this floristic diversity, five families are the most represented. These are Asteraceae, Fabaceae, Poaceae, Solanaceae and Verbenaceae. Most species of the Asteraceae and Poaceae family proliferate rapidly by wind (anemoria) when they reach the fruiting stage [13]. According to Mangara [14], this mode of spread by wind allows them to colonize cultivated environments very quickly. The predominance of families such as Asteraceae, Fabaceae, Poaceae and Solanaceae has been observed by Bakayoko [15]. The dominance of these four families was also noted by Boraud [16] and Traoré and al. [17]. These families can be found on the list of ten families considered by Akobundu [18], as "major world weeds", which are: Poaceae, Asteraceae, Cyperaceae, Amaranthaceae,
Fabaceae, Convolvulaceae, Euphorbiaceae, Malvaceae, Solanaceae and Polygonaceae [18]. Work carried out by Kouakou [19] in maize cultivation in M'bahiakro Department showed that species of the Asteraceae, Poaceae and Fabaceae families are in the majority. These observations were also made in the work carried out in the Mediterranean region by Maillet [20] and Loudyi [21]. Indeed, these authors found in the course of their work that the Poaceae, Asteraceae and Fabaceae are the most representative families. The predominance of broadleaf trees $(85.06 \%)$ in this wo rk, was also observed in pineapple cultivation in Morocco by Bouhache and Chougrani [22], Taleb and Maillet [23], Tanji and Boulet [24], with respectively $82.3 \%, \quad 87 \%$ and $84 \%$ of their flora. This high representativeness of the broadleaved trees has also been mentioned in several works such as: the work of Kouamé Kra [25] in the District of Yamoussoukro in rice cultivation and that of Kouakou [19] in maize cultivation in the Department of M'bahiakro. In addition to these results, the strong presence of broadleaf trees was also noted in northern Côte d'Ivoire in sugar cane cultivation by Boraud [16]. According to Déat [26], there is no weed flora specific to a given crop, but rather to ecological parameters and agronomic factors.

Table 3. Indices of specific diversity of weed families

\begin{tabular}{llll}
\hline Family & G & E & Ids \\
\hline Asteraceae & 8 & 9 & 1,12 \\
Fabaceae & 5 & 6 & 1,2 \\
Poaceaa & 3 & 4 & 1,33 \\
Solanaceae & 1 & 3 & 3 \\
Verbernaceae & 1 & 3 & 3 \\
\hline
\end{tabular}

Legend: $G$ = genre; $E$ = species; $I d s$ = Specific index
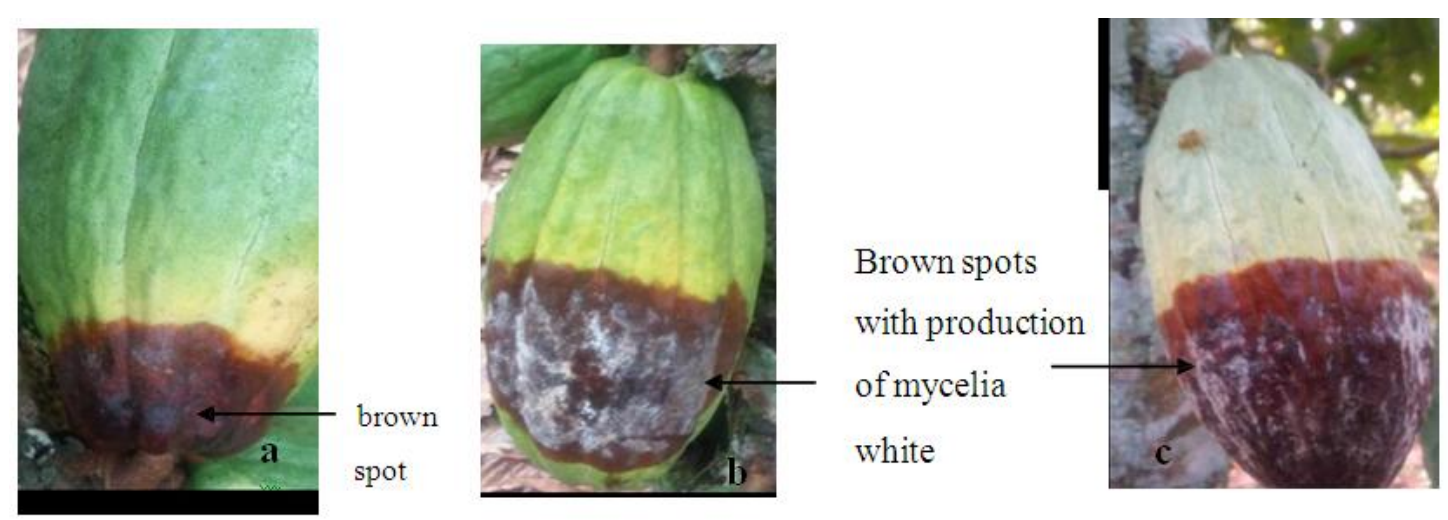

Fig. 1. Symptom of brown rot observed on the pods in the field a: proximal infection; b: lateral infection; $c$ : distal infection 

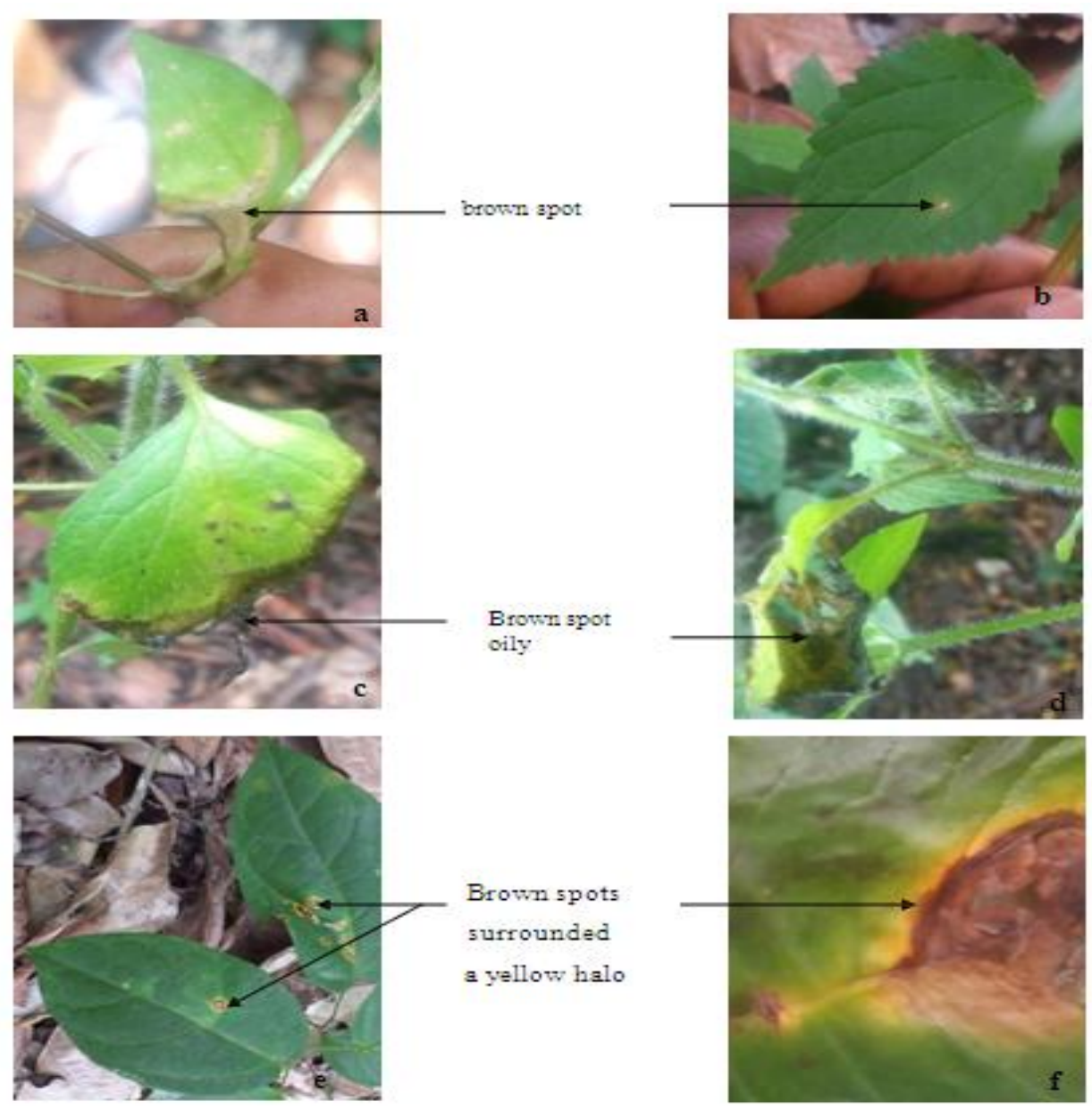

Fig. 2. Different types of symptoms observed on cocoa weeds in the field a: leaf of Oplismenus burmannii (Poaceae); b: leaf of Laportea aestuans (Urticaceae);
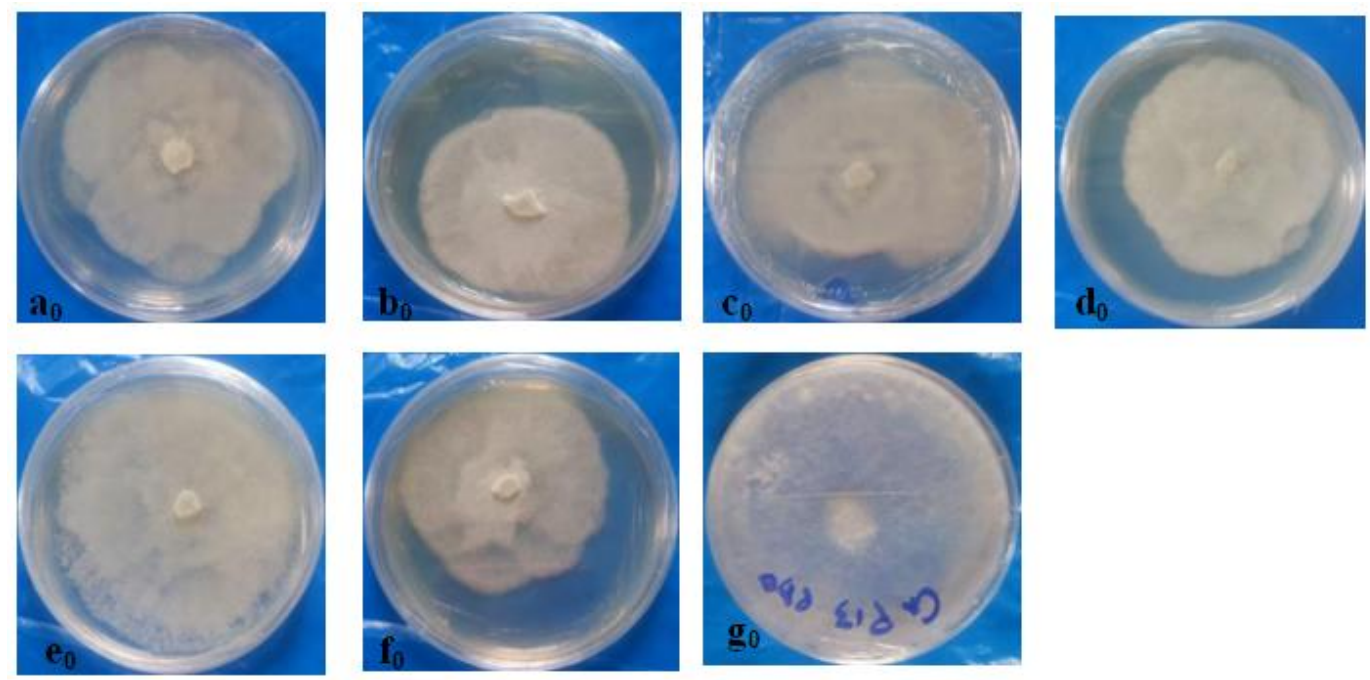

Fig. 3. Morphological colonies of Phytophthora isolated from pods on PDA media 

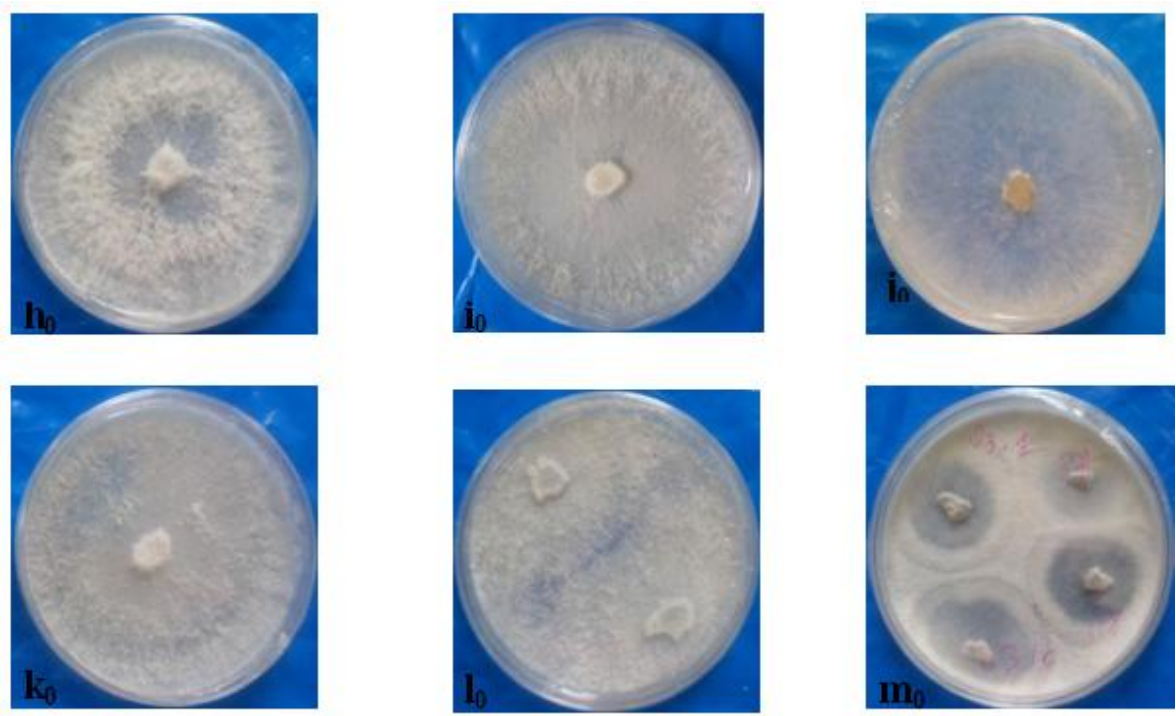

Fig. 4. Morphological colonies of Phytophthora isolated from weeds on PDA media
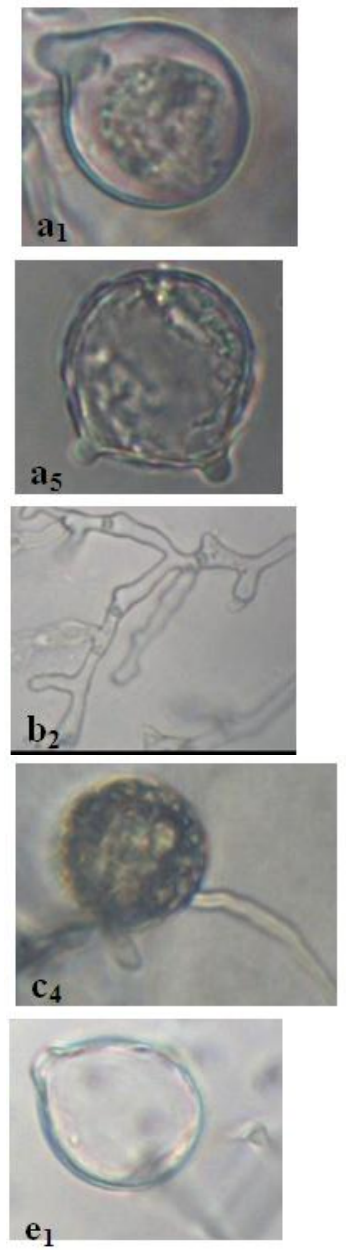
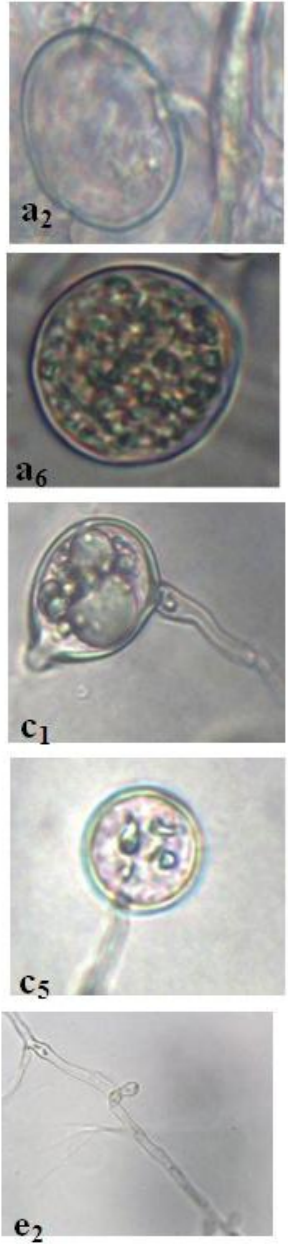
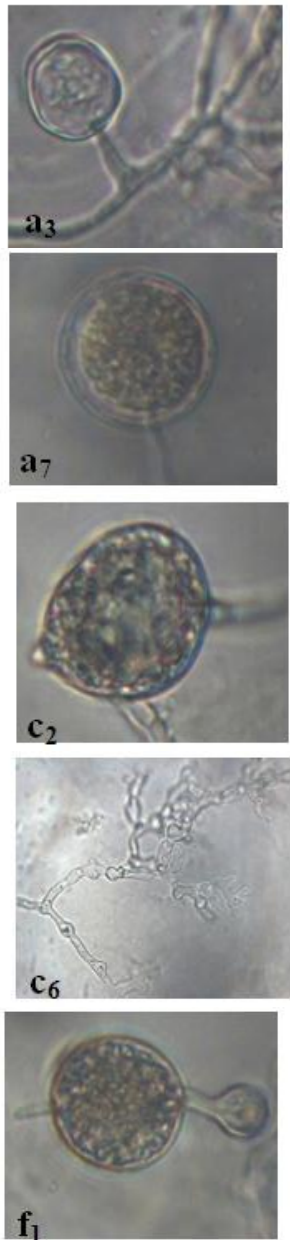
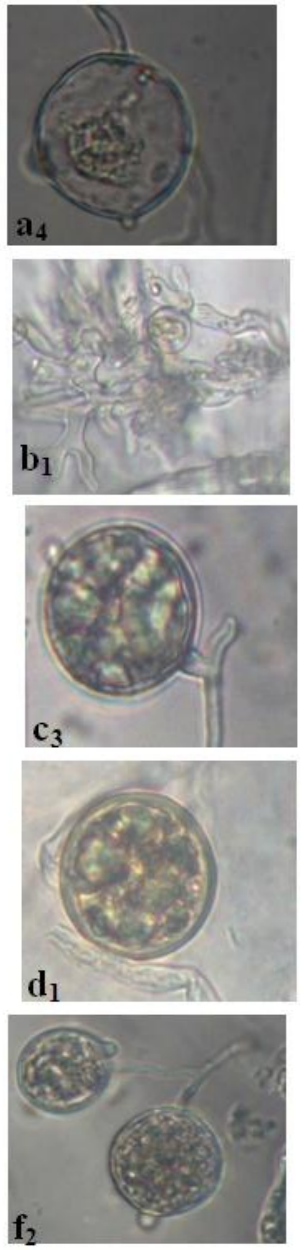

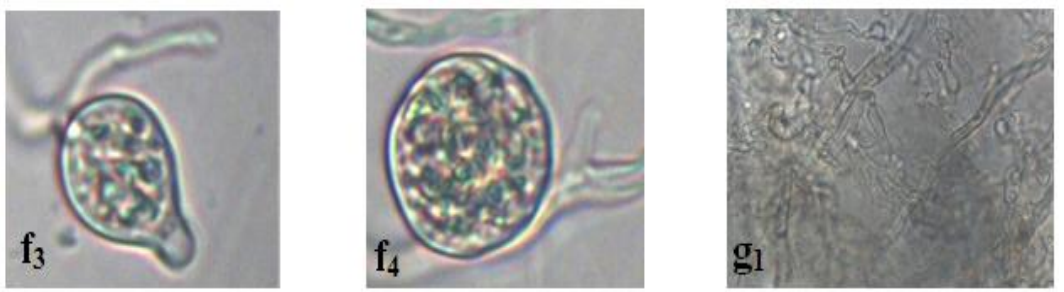

Fig. 5. Microscopic structures of Phytophthora spp. formed on PDA medium isolated from pods

a1 and e1: Ovoid Sporangium with rounded papilla; a2 and a3: Clamydospores; a4: Spherical Sporangium with pointed papilla and long pedicel; a5: Spherical Sporangium with two rounded papillae; a6: Ovoid Sporangium; a7, c4, c5 and f4: Spherical Clamydospores; b1, b2, c6, e2 and g1: Uncompartmentalized Mycelium; c1 and f2: Spherical Sporangia with rounded papillae and long pedicels; c2: Ovoid Sporangia with pointed papilla and long pedicel; c3 and d1: Spherical Oospore; f1: Spherical Sporangia with pointed papilla and long pedicel as a drain;

f3: Ovoid Sporangia with rounded papilla and short pedicel; f4: Spherical Sporangia with rounded papilla and short pedicel
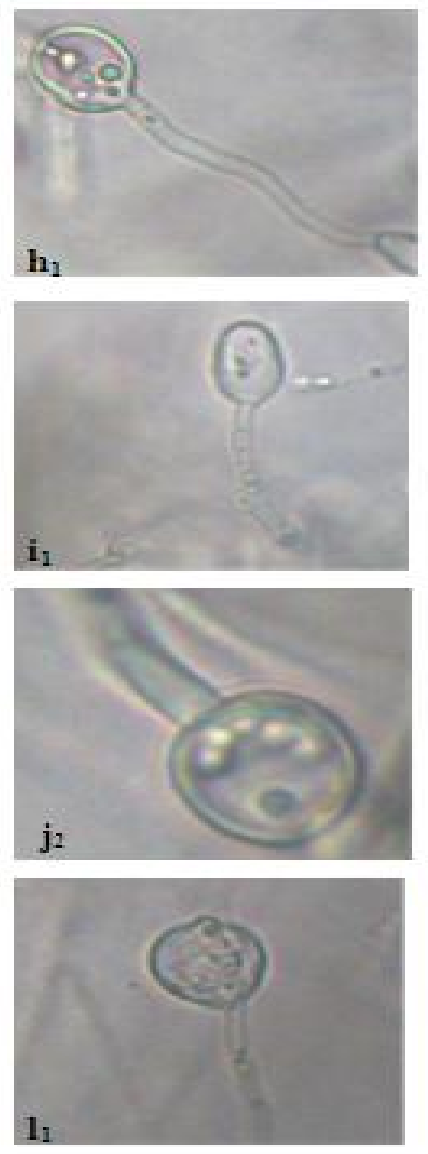
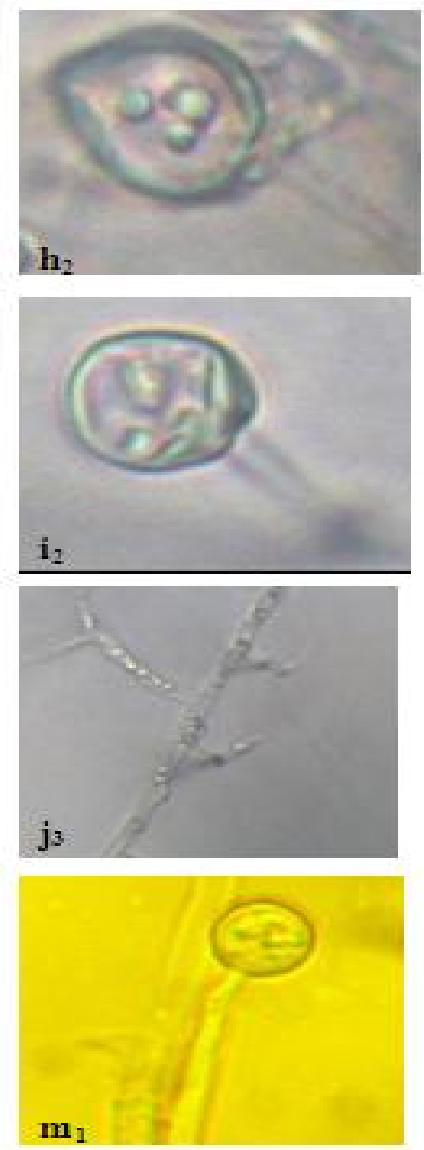
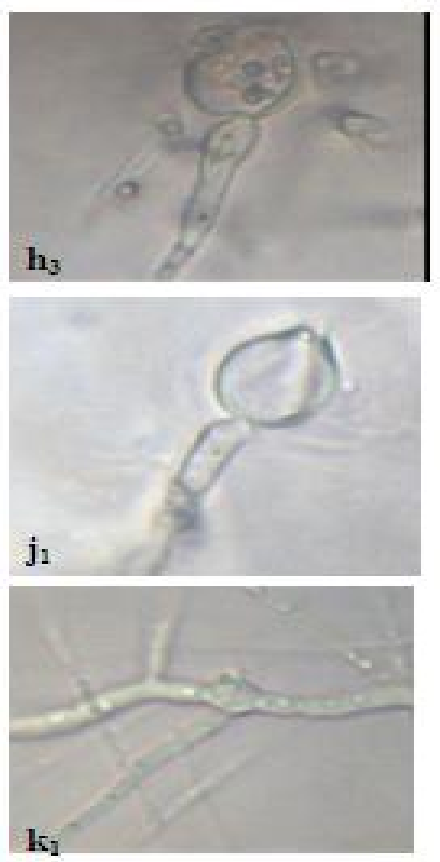

Fig. 6. Microscopic structures of Phytophthora spp. formed on PDA medium isolated from weeds

h1: Ovoid Sporangium without papilla; h2: Semi rounded ovoid Sporangium; h3: Spheroid Sporangium without papilla; i1: Ovoid Sporangium without papilla; i2 : Spherical Sporangium without papilla; 11 : Ovoid sporangium with rounded papilla; j2: Spheroid sporangium without papilla; 33 and k1: Uncompartmentalized mycelia; 11:

Rounded semi-papillated spheroid sporangium; m1: Spherical clamydospore 
Based on observations of infected pods collected from cocoa fields, symptoms of brown rot appeared as brown spots. These brown spots developed at the peduncular, lateral and distal ends of the pods. The surface of the infected pods was covered with whitish mycelium. In addition, pods with these brown spots are hard to the touch. These results would indicate that the symptoms observed are characteristic of Phytophthora palmivora or $P$. megakarya. These symptoms are similar to those described on pods by Adabe and NgoSamnick [27] and [28] as those of brown rot of cocoa pods. In addition to the symptomatic remarks made by these authors, [29] and [30] observed lesions in their studies that initially had a translucent appearance. According to these authors, these lesions develop into brown rot which are hard to the touch and in the final stage become covered with a sporiferous creamy-white coating. Concerning the observations made on weeds, brown necroses were observed on the leaves of Oplismenus burmannii, and Laportea aestuans. On the leaves of Clerodendrum splendens and Xanthosoma mafaffa, brown necrotic lesions surrounded by a yellow halo were noticed. Oily brown necrotic lesions were examined on the leaves of Ageratum conyzoides. These observations are similar to those made by Kerroum [31] on leaves and stems of Solanum tuberosum and Solanum lycopersicum. This author revealed brown necrotic lesions surrounded by a pale to yellowish ring on the infected areas of these two species. These brown necroses were also observed inside the fruit s of Solanum tuberosum [32]. According to [31] and [32], these symptoms are due to Phytophthora infestans which causes late blight disease in Solanaceae. In addition to these observations, [33] noted the appearance of discoloured spots with an oily appearance and then brown with a light green border that appear on the upper surface of the leaves of Solanum tuberosum. And on the underside of these leaves, a white down that appears on the circumference of the necrotic zone. On the petioles and stems of this same species, brown spots are also observed by this author. Tubers of Solanum tuberosum mildewed show purplish to brown spots on the epidermis [33]. In addition to these observations, studies by Jackson and Wright [6] showed that lesions on the leaves generally have a brown or greyish center surrounded by a yellow halo. On leaves, the center of these lesions sometimes punctures, leaving a round hole [6]. According to [34] and
[35] cited by Pohe and al. [36], these phytophthora rots are rain-related. Indeed, rain favours the installation and development of Phycomyces diseases such as brown pod rot due to Phytophthora. It creates favorable conditions for their reproduction and the dissemination of their propagules. Thus, water appears to be the indispensable element, especially in the initiation and maintenance of the epidemic [37].

Seven strains of phytophthora were isolated from weed symptoms during this study. This result reveals that the cocoa crop of Côte d'Ivoire contains plant species that are potential hosts for Phytophthora. According to [38], Phytophthora species are able to survive several years in the soil and can attack plants when conditions become favourable. Indeed, the pedoclimatic conditions of cocoa trees being favourable, Phytophthora strains could live there for several years in its preservation structures such as chlamydospores, sporangia and oospores on weeds. These Phytophthora species isolated from the weeds could be potential sources of infection of pods with brown rot and cause considerable losses.

The macroscopic and microscopic characteristics of the observed Phythophthora strains were described by Yao [39] and Jung and al. [40] on PDA culture medium. Phythophthora strains obtained from the pods were macroscopically characterized by white thallus with a cottony appearance. These strains of Phythophthora showed lined mycelial colonies that diffuse into the culture medium. These mycelial colonies without pigments have regular and irregular contours. These same macroscopic features were also observed on Phythophtora strains obtained from weeds. These remarks were also made by Yao [39] during his work on the diversity of fungal flora in soils of the cocoa rhizosphere in Côte d'Ivoire. Indeed, this author indicated during his observations that Phythophtora have fibrous, aerial, fluffy white Thalles with irregular growth whatever the zone of origin of pods and soils of cocoa trees. At the microscopic level, sporangia of different forms with or without papillae and pedicels or not, formed on PDA culture media were observed. Microscopic structures such as Spherical Clamydospores and Spherical Oospore were also examined in this study. The same microscopic observations were made by Yao [39] and Pohe [41] on PDA culture media. These authors highlighted during their study the 
presence of ovoid sporangia with rounded apex, ovoid sporangia with reduced pedicel, spheroid sporangia with pointed apex and long pedicel, spherical terminal Chlamydospore, spherical Oospore and branched and non-partitioned mycelia. In addition to the observations made by these authors, Jung and al. [40] made the same remarks on V8 culture medium.

\section{CONCLUSION}

The inventory carried out in cocoa farms identified 48 weeds that could be hosts for Phytophthora. The study of the morphological characterization of these weed hosts susceptible to Phytophthora showed that among them, five are potential hosts of Phytophthora. They are: Ageratum conyzoides (Asteraceae), Clerodendrum splendens (Verbenaceae), Laportea aestuans (Urticaceae), Oplismenus burmannii (Poaceae), Xanthosoma mafaffa (Araceae). The Phytophthora strains obtained from these weeds were characterized by airy, pigment-free, regular and fluffy looking white thallus. However, some strains present white mycelial colonies with a lined appearance. At the microscopic level, all Phytophthora strains showed an unsegmented mycelium. This study shows that there are potential host plants for Phytophthora in cocoa plantations in the Nawa Region of South- Western Côte d'Ivoire. Therefore, regular weeding of the plantations should be carried out by farmers to eliminate potential Phytophthora weed hosts responsible for brown rot. Weeding should also be carried out before the application of fungicide against the pathogen. In addition, growers often have to prune cocoa trees to allow sunlight to penetrate the plantations.

\section{COMPETING INTERESTS}

Authors have declared that no competing interests exist.

\section{REFERENCES}

1. ICCO (International Cocoa Organization). ICCO monthly review - February 2016. ICCO. Londres WC1A. Royaume Uni. 2016;2.

2. Anonymous. Cocoa in Côte d'Ivoire. Economic missions. MINEFI- DGTPE. 2005;4.

3. Tra Bi CS. Specific diversity and termite damage in cocoa trees (Theobroma cacao L., 1753) from the Oumé region in the Ivory Coast. Doctoral thesis of Agricultural Entomology, UFR Biosciences, Félix Houphouët -Boigny University, Abidjan, Ivory Coast. 2013;20.

4. N'Guessan KF, Coulibaly N. Population dynamics of mirids and some other cocoa pests in the western region of Côte d'Ivoire. Proceedings of the thirteenth international conference on cocoa research. Kota Kinabulu, Sabah, Malaysia. 2000;425-429.

5. Nyasse S, Efombagn MIB, Kebe BI, Tahi $M$, Despreaux D, Cilas C. Integrated management of Phytophthora diseases on cocoa (Theobroma cacao L): Impact of plant breeding on pod rot incidence. Crop Protection. 2007;26:40-45.

6. Jackson GVH, Wright JG. Plant protection. Secretariat of the Pacific Community. 2011;7:1-4.

7. Hovenden MJ. Distinguishing between acclimation and adaptation. Taylor ans Francis Group, New York, pop. 2007;333336.

8. Ake-Assi L. Flora of the Ivory Coast: Descriptive and biogeographical study with some ethnobotanical notes. State Doctorate Thesis in Natural Sciences. Faculty of Science and Technology, National University, Abidjan, Ivory Coast. 1984;665.

9. CNRA. Guide to controlling the disease of the cocoa swollen shoot in Ivory Coast. First edition. 2011;19.

10. Singo SN. Wild hosts of the caterpillars of Achaea catocaloides guenee, defoliators of cocoa crops in the Regions of AgnebyTiassa and Belier in Côte d'Ivoire. Master of Biodiversity and Ecosystem Valuation, Systematic specialty, Plant Ecology and Biodiversity, Weed science option, UFR BIOSCIENCES, Félix Houphouët-Boigny University, Ivory Coast. 2016;62.

11. Kpangui KB. Dynamics, plant diversity and ecological values of cocoa-based agroforests in the center of Côte d'Ivoire: case of the Kokumbo sub-prefecture. Doctoral thesis, Félix Houphouët-Boigny University, Abidjan, Ivory Coast. 2015;169.

12. Adou Yao CY. Peasant practices and dynamics of biodiversity in the classified forest of Monogaga, Ivory Coast. Doctoral thesis, Natural Men Societies Department, MNHN, Paris. 2005;238.

13. Mangara A. Weeds in pineapple cultivation: Ananas comosus (L.) Merr. (Bromeliaceae), in the localities of 
Anguédédou, Bonoua and N'douci, in the lower Ivory Coast: inventory and control test. PhD thesis in Plant Ecology (Option Weedbology), UFR Biosciences, University of Cocody, Abidjan, Ivory Coast. 2010;102107.

14. Yapi AF. Major weeds and technical itineraries for weeding food crops in the Mé region, in the south-east of the Ivory Coast: the case of plantains and cassava. Doctoral thesis, Félix Houphouët Boigny University, Cocody, Abidjan, Ivory Coast. 2017;171.

15. Bakayoko GA. Yam cultivation in M'Bahiakro Center-East of Côte d'Ivoire: socio- demographic characteristics and grass cover management. Doctoral thesis, Félix Houphouët- Boigny University, Abidjan, Ivory Coast. 2017;182.

16. Boraud NKM. Floristic and phytoecological study of weeds of the sugar complexes of Ferké 1 and 2, Borotou -Koro and Zuénoula, in Ivory Coast. Doctoral thesis, 3rd Cycle, UFR Biosciences, University of Abidjan- Cocody. 2000;157.

17. Traoré K, Pene CB, Aman K, Aké S. Phytosociology and floristic diversity of the elaeicultural perimeter of Mé in the lower forested Ivory Coast. African Agronomy. 2005;17(3):163 -178.

18. Akobundu IU. Weed Sciences in tropics. Principles and practices. Wiley, Chichester, UK. 1987;522.

19. Kouakou Nanan J. Influences of the main weeds on the production of maize (Zea mays) in M'Bahiakro in the Center-East of the Ivory Coast. PhD thesis of the University Felix Houphouet Boigny UFR Biosciences. 2016;137.

20. Maillet J. Control of grassy weeds intropical cereals. In: Baker FWG, Terry PJ. Tropical Grassy Weeds. CASAFA reports, Series n 2, C. A. B. Int. 1991;112143.

21. Loudyi MC. Botanical and ecological study of the vegetation of the plateau of Meknes (Morocco). Doctoral thesis, USTL, Montpellier, France. 1985;153.

22. Bouhache $\mathrm{M}$, Boulet $\mathrm{C}$, Chougrani A. Floristico-agronomic aspect of weeds in the Loukkos region (Morocco). Weed Research. 1994;34:119-126.

23. Taleb A, Maillet J. Weeds of the Chaouia cereals (Morocco). Floristic aspect. Weed Research. 1994;26:159-66.
24. Tanji A, Boulet C. Biological diversity of weeds in the Talda region (Morocco). Weed Research. 1986;26:159-66.

25. Kouamé Kra F. Biology and ecology of major weeds in rice cultivation in the ram region in central Côte d'Ivoire. Thesis from Felix Houphouët Boigny University. UFR Biosciences. 2014;186.

26. Deat $\mathrm{M}$. The weeds of cotton crops in the Ivory Coast. Cotton and Tropical Fibers. 1976;31(4):419-427.

27. Adabe KE, Ngo-Samnick EL Production and processing of Cocoa. Pro-Agro collection. 2014;44.

28. Coulibaly K, Kébé BI, Aka AR, Kouakou K, N'Guessan WP, Tahi GM, Kassin KE, Guiraud SB, Assi ME, Koné B, N'Guessan $\mathrm{KF}$. Fight against brown rot cocoa pods in Côte d'Ivoire. Cocoa tree technical sheet $n$. National Center for Agronomic Research. 2017;6:2.

29. Sonii D. Discovering sustainable cocoa production: participatory training guide for growers. Integrated pest management. Sustainable Tree Crops Program, International; 2005.

30. Fossouo KAL. Spatial-temporal development of brown rot in fruits Cocoa trees: Case of two peasant plots From the provinces of central and southern Cameroon. Thesis for obtaining the Master in Applied Statistics. University of Yaoundé 1, École Nationale Supérieure Polytechnique, Department of Mathematics and Physical Sciences. Institute of Tropical Agriculture. Yaoundé, Cameroon. Version March 2005; 2006;93.

31. Kerroum F. Identification and characterization of Phytophthora infestans pathogen of late blight of potato and biological control test. Doctoral thesis. University of Oran - 1 AHMED BEN BELLA, Algeria. 2009;132.

32. Nelson NC. Late bligth of tomato (Phytophthora infestans). plant Disease. Cooperative extention service. College of Tropical Agriculture and Human Resources; 2008.

33. Milliard JM. Phytophthora infestans, the name of potato late blight says it all. Succeed the Normand farmer. Normandy Agricultural Press, vegetable-production. 2018;3.

34. Babacauh KD. Structure and dynamics of populations of Phytophthora spp. cocoa pest (Theobroma cacao L.) These Doctor 
of State, Orsay University No. 2344. 1980;180.

35. Duniway JM. Water relation of water molds. Annu. Rev. Phytopathol. 1979;17:431-460.

36. Pohe J, Koula J, Rabe GR, Dezai LR. Aggressiveness of brown rot in cocoa pods in the south-east of Cote d'Ivoire. Journal of Animal \& Plant Sciences. 2013;20(2):3126-3136.

37. Brasier CM, Hansen EM. Evolutionary biology of Phytophthora, Part.II: Phylogeny, speciation, and population structure. Annu. Rev. phytopathol. 1992; 30:173-200.

38. Perrin R. Diagnosis of diseases of land-based origin in forest nurseries. National Institute of Agronomic Research.
Research Station on Pathogenic Flora in the Soil. 1988;105-109.

39. Yao KF. Diversity of fungal flora in soils of the rhizosphere of cocoa trees in Côte d'Ivoire. Master's thesis, Option: plant and environmental protection, Nangui Abrogoua University, Abidjan, Ivory Coast. 2013;45.

40. Jung T, Stukely MJC, Hardy GEStJ, White D, Paap T, Dunstan WA, Burgess TI. Multiple new Phytophthora species from ITS Clade 6 associated with natural ecosystems in Australia: evolutionary and ecological implications. Persoonia. 2011;(26):13-39.

41. Pohe J. Phytophthora spp. agents of diseases of various plants. Rev. Ivory. Sci. Technol. 2012;(19):72-87.

(c) 2021 Baka et al.; This is an Open Access article distributed under the terms of the Creative Commons Attribution License (http://creativecommons.org/licenses/by/4.0), which permits unrestricted use, distribution, and reproduction in any medium, provided the original work is properly cited.

Peer-review history:

The peer review history for this paper can be accessed here: http://www.sdiarticle4.com/review-history/65515 